\title{
Evaluating the Effectiveness of Public-Private Partnership Policy in Iran's Public Sector
}

Hossein Alipour ${ }^{1}$ Assistant Professor, Department of Management, Institute for Management and Planning Studies, Tehran, Iran, (Corresponding Author).

Qaneh Mamandi' ${ }^{2}$ M.A. in Public Administration, Institute for Management and Planning Studies, Tehran, Iran.

Ramin Rahnavard M.A. in Executive Management, Tehran Province Water and Wastewater Company, Tehran, Iran.

\begin{abstract}
Public-private partnership policy is what public organizations have taken to carry out their development projects in recent years. The purpose of the present study is to identify the effectiveness of publicprivate partnership policy implementation in the Iranian public sector. The statistical population of this study included those organizations of the public sector which have all adopted public-private partnership policy. Using systematic random sampling method, 126 organizations were selected through Morgan's table. To collect data, researchermade questionnaires were distributed among the subjects. Based on such factors as economic efficiency, financial justice, redistributive justice, compatibility with public ethics, adaptability and accountability, results show that the effectiveness of public-private partnership policy implementation is significant. Public-private partnership project holders can improve the context for developing and implementing public-private partnership projects by emphasizing and applying the suggested solutions of this research.
\end{abstract}

Keywords: Public-private Partnership, Evaluation, Economic Efficiency, Financial and Redistributive Justice, Alignment with Public Ethics, Adaptability, Accountability.

1.h.alipour@imps.ac.ir

2.gh.mamandi@imps.ac.ir 


\section{مقدمه}

در طول دو دهه كذشته، ارائه خدمات زيرساختى از طريق بخش خصوصى، كه اغلب به نام

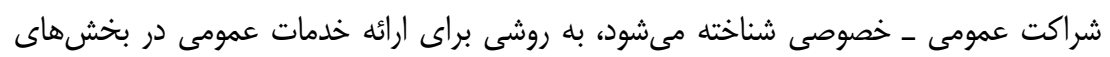

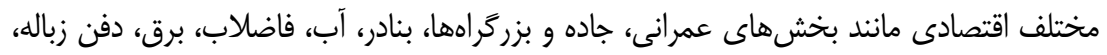

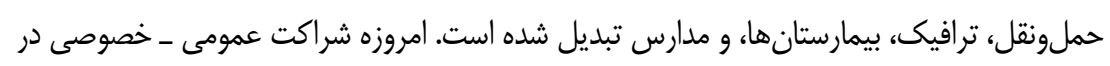
سراسر دنيا، حتى در حكومتهاى سوسياليستى يا كمونيستى، گسترش مى ئى يابند (Yong, 2010).

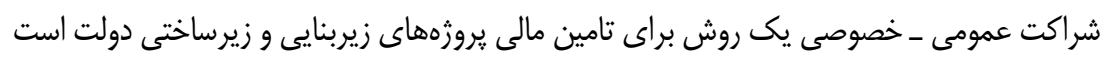

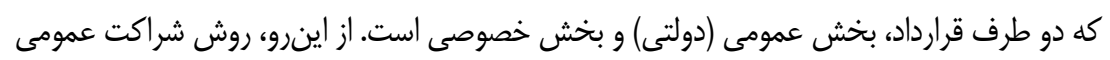
ـ خصوصى مى تواند مزاياى دوكانهاى داشته باشد، مانند فراهم آوردن سرمايه براى كشورهايى كه

داراى منابع محدود هستند، و براى اجراى بهتر يروزهها (Park et al., 2018). در سالهاى اخير، اين خطمشى در ايران در قالب برنامههاى توسعه و برخى از قوانين تدوين شده و به اجرا گذاشته شده است. البته تنها قانونى كه بهصراحت به روش شراكت عمومى -خصوصى تاكيد

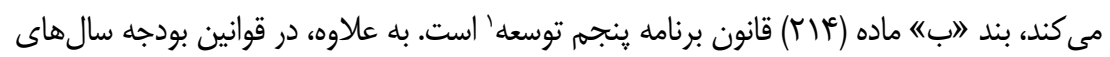

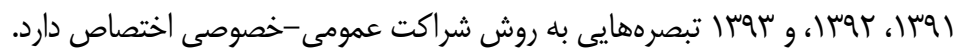
سازوكار شراكت عمومى ـ خصوصى در كشورهاى درحالتوسعه يكى از ابزارهاى تامين منابع

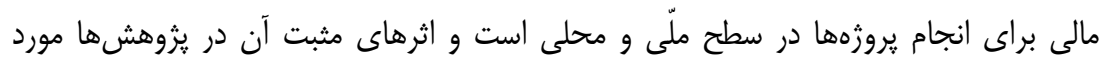

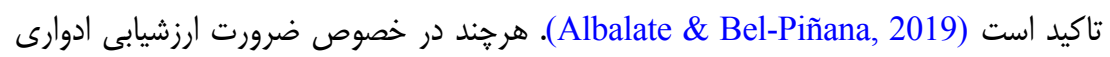
करें

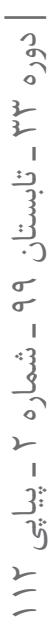

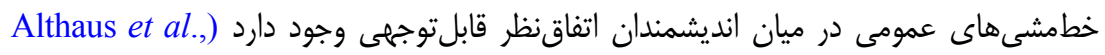

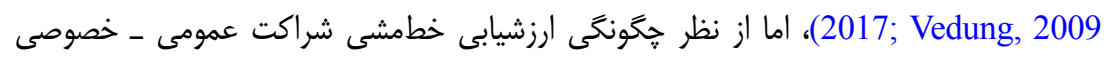
اختلافنظر مشهودى بين صاحبنظران خطمشى گذار ديده مىشود (Liu et al., 2015). بايد در نظر داشت كه برخى يزوهشگران با تمركز بر جنبه خاصى مانند ريسك شراكت عمومى -

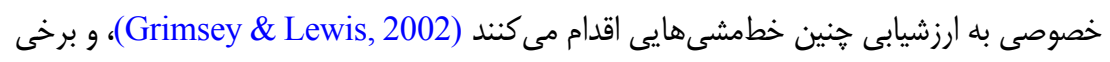
ديخر وجوه مختلف شراكت عمومى ـ خصوصى را با انتخاب معيارهاى عام مورد ارزشيابى قرار

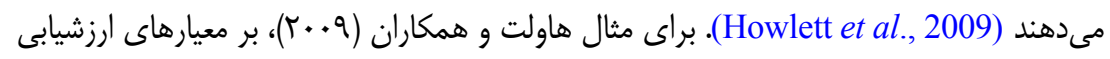




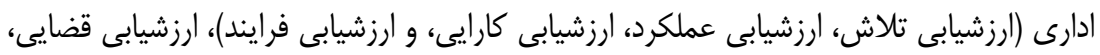

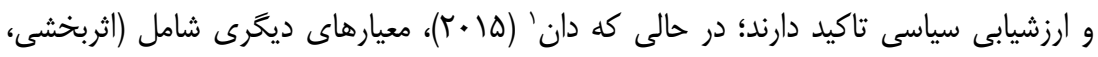

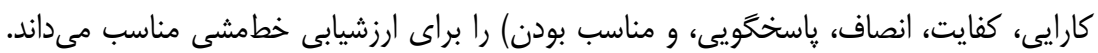

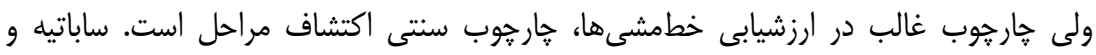

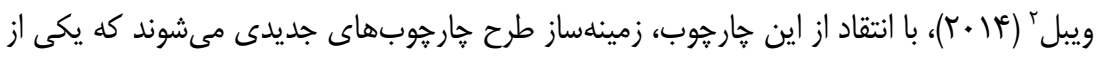

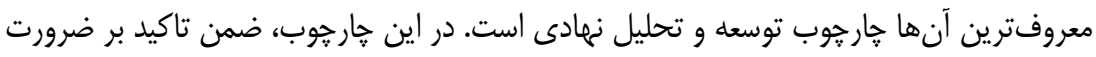
ارزشيابى خطمشى، معيارهاى جديدى براى ارزشيابى خطمشى مطرح مىشود (Ostrom, 2009)، كه در اين يزوهش براى ارزشيابى خطمشى شراكت عمومى ـ خصوصى در ايران بكار كرفته

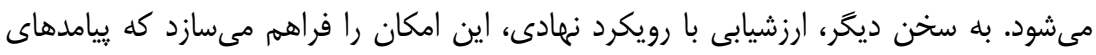

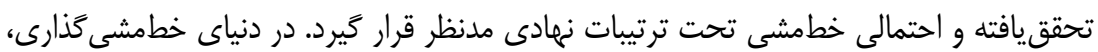
فرايند خطمشى تذارى زمانى كامل مى شود كه خطمشى به مرحله ارزشيابى برسد و نقايص و

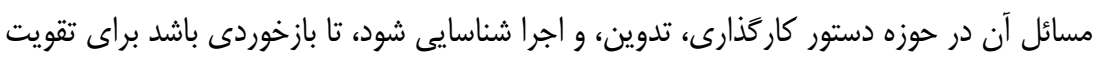

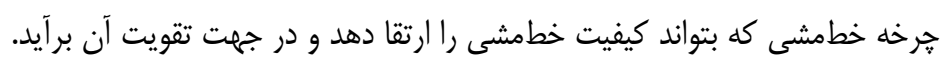

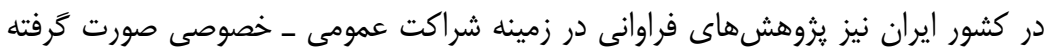

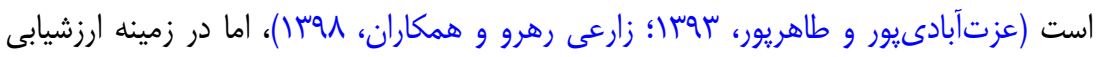

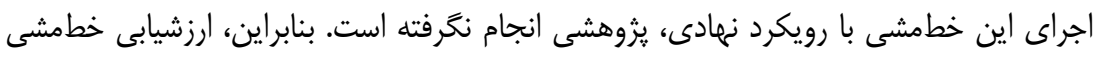

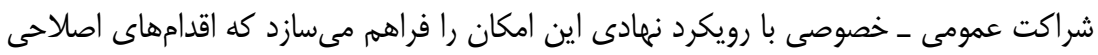

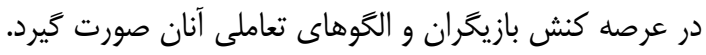

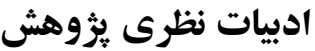

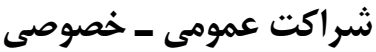

شراكت عمومى ـ خصوصى (PPP) در سالهاى اخير بسيار وسعت يِيدا مى كند و از جنبههاى مختلف به عنوان يديده سياسى، فنى، و اقتصادى تعريف مى شود (Hodge \& Greve, 2018).

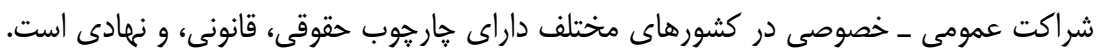

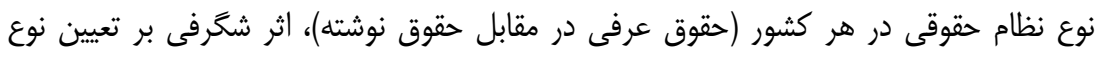

1. Dunn

2. Sabatier \& Weible

3. Public-Private Partnership 
جارجوب مقرراتى براى شراكت عمومى ـ خصوصى دارد. بلهور معمول، كشورهايى كه داراى حقاى

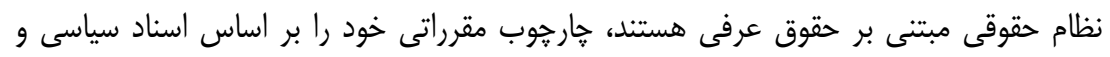

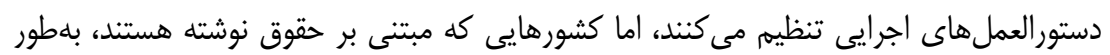

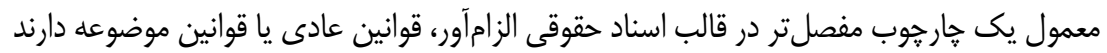

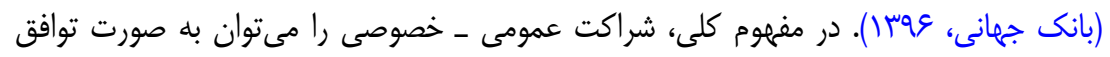

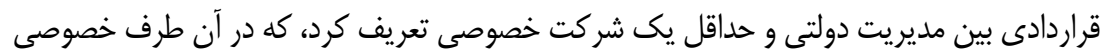

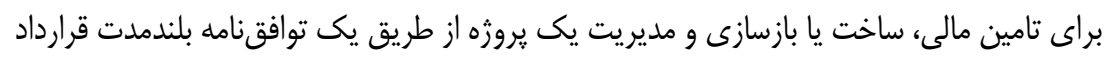

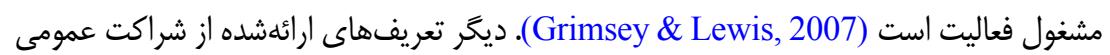
ـ خصوصى در جدول (1) منعكس است.

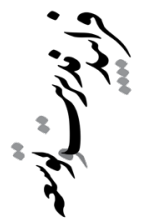

جدول ا: تعريف شراكت عمومى ـ خصوصى

\begin{tabular}{|c|c|}
\hline & \\
\hline 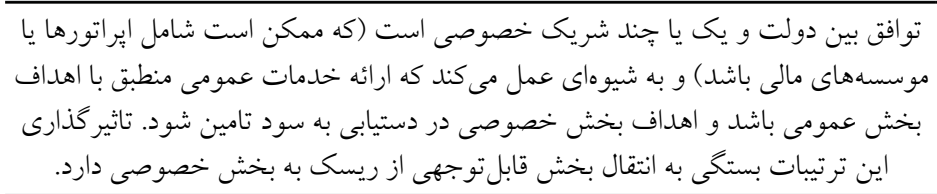 & زمان همكارى \\
\hline 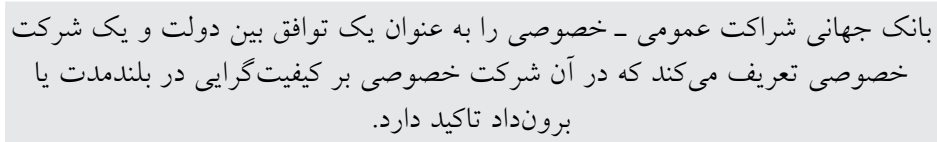 & $\begin{array}{l}\text { و } \\
r \text { r. } \\
\text { (r. }\end{array}$ \\
\hline 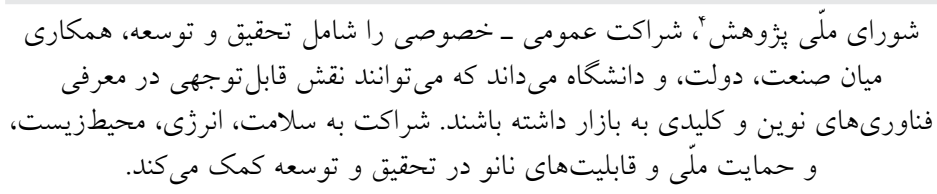 & 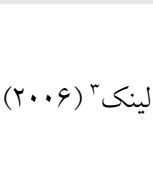 \\
\hline 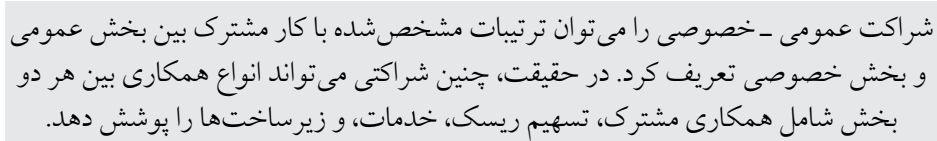 & $\begin{array}{l}\text { هاو كسورث } \\
(Y \cdot 11)\end{array}$ \\
\hline
\end{tabular}

1. OECD

2. Robinson et al.

3. Link

4. National Research Council

5. Burger \& Hawkesworth 


\section{مبانى نظرى شراكت عمومى ـ خصوصى}

\section{ساختار كر ايیى توسعه}

ساختاركرايى، يك نظريه توسعه محسوب مىشود كه بر جنبههاى ساختارى و ايجاد دگَر كونى در آن تاكيد دارد. مطابق اين نظريه، توسعه مستلزم تغييرها در ساختارهاى اقتصادى جامعله است. شراكت عمومى-خصوصى در حقيقت ساختار جديدى را در انجام بروزههاى توسعه در سطوح

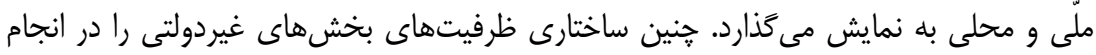
يروزههاى توسعه بكار مى گيرد (Hitchler \& Domann, 2007).

\section{رويكرد شبكهاى}

اين رويكرد يا نظريه با مد نظر قرار دادن نقش حكومت و بازيخران اجتماعى در خطمشى گذارى، رويكر دهاى حكومتمحور و جامعلمحور راتلفيق مى كند. رويكرد شبكهاى نهتنها انواع مختلفى از بازيخران راد بر مى يرد، بلكه ايجاب مى كند تعامل بين آنها نيز مد نظر قرار گيرد.در رويكرد شبكهاي بازيخران به هيج وجه به عنوان افراد منفك و جزءشده تصور نمىشوند، بلكه به عنوان افراد متقابلاً به هم وابسته نكخريسته مىشوند (Sabatier, 1991). همجِنين، شراكت عمومى _خصوصى بلنوعى متشكل از بازيخران عمومى و خصوصى است كه به صورت شبكهاى در انجام يروزههاى زيرساختى دولت عمل مى كند.

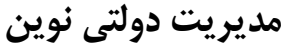

ابر انغاره مديريت دولتى نوين' در واكنش به نارسايىهاى الكَوى اداره امور عمومى در بخش

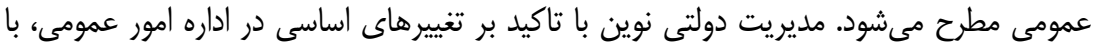

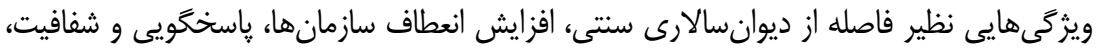

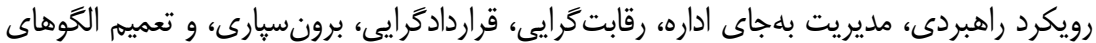
مديريت بخش خصوصى به بخش دولتى شناخته مى شود (Hughes, 2012). در حقيقت، يكى از ويزگىهاى مهم مديريت دولتى نوين توجه به كاهش وظايف دولت از طريق خصوصى بازى و

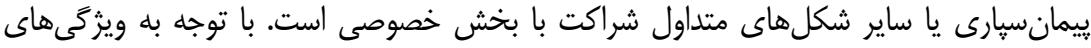
ذكرشده اكر بخواهيه به صورت تخصصى ادبيات شراكت عمومى ـ خصوصى را بررسى كنيه، بائه 
اين مفهوم اشاره دارد به ابرانغاره مديريت دولتى نوين كه تاكيد بر مشترى گرايى، خصوصىسازى، تضعيف حكومت، ترويج راست كرايى افراطى عليه دولت، مديريت

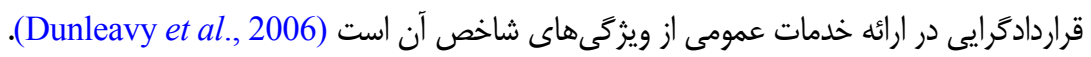

\section{ارزشيابى خطمشى}

ارزشيابى خطمشى با استفاده از طيف وسيعى از روشهاى يزوهش بلهطور نظاممند، كاوش

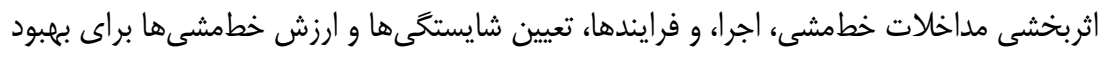
شرايط اجتماعى و اقتصادى ساير ذى نفعان مختلف محقق مى شود (Treasury, 2007). ارزشيابى إنى

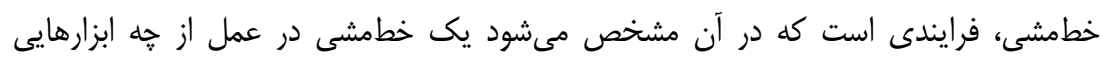

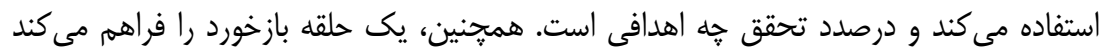

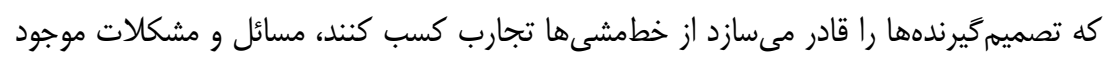

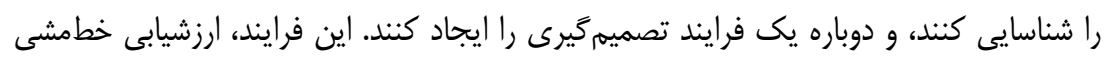

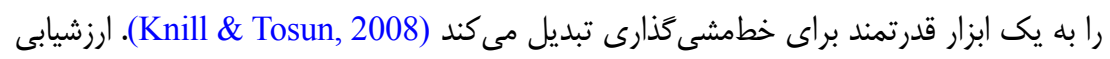

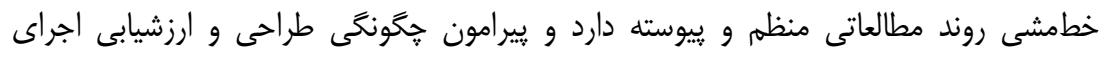

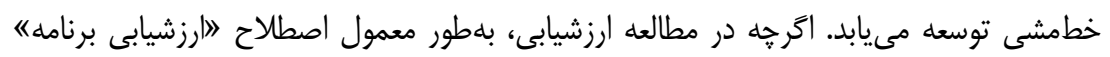

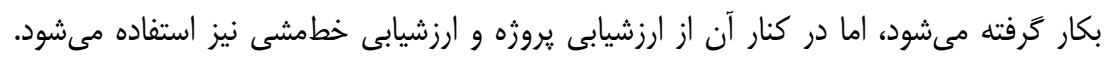

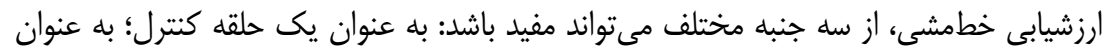

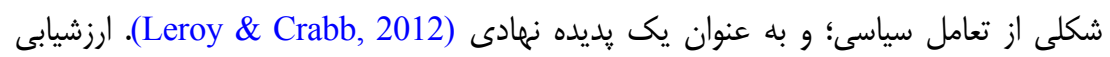

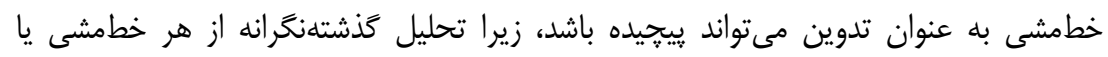

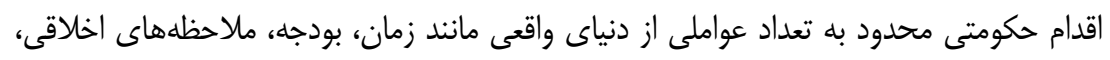

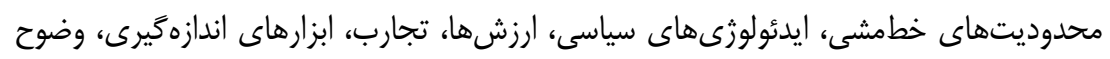
هدف، و تعصبهاى نمادى است (Juma \& Onkware, 2015).

\section{انواع ارزشيابى}

انديشمندان خطمشى گذارى مبانى مختلفى را براى طبقلبندى ارزشيابى خطمشى انتخاب مى كنند.

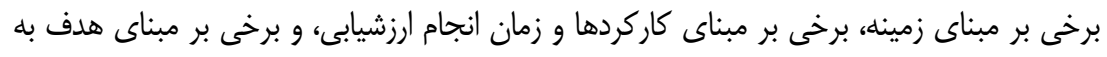

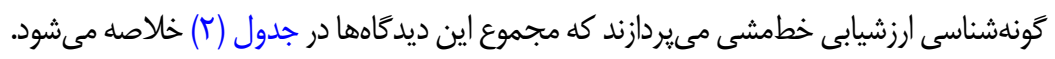


جدول r: انواع ارزشيابى خطمشى (رهنورد و رهنورد، Vوسا)

\begin{tabular}{|c|c|c|}
\hline انواع ارزشيابى & منبع & رديف \\
\hline ارزشيابى توسعهاى؛ ارزشيابى سازنده؛ ارزشيابى پِايانى & اسكريون' (1991) & 1 \\
\hline يِشارزشيابى؛ ارزشيابى مستمر؛ پِ يسارزشيابى؛ فرارزشيابى & 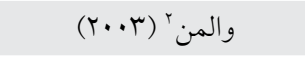 & r \\
\hline ارزشيابى ادارى؛ ارزشيابى قضايى؛ ارزشيابى سياسى & 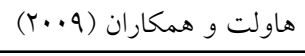 & r \\
\hline
\end{tabular}

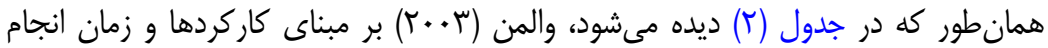
ارزشيابى، انواع ارزشيابى خطمشى را به شرح زير طبقهبندى مى كند:

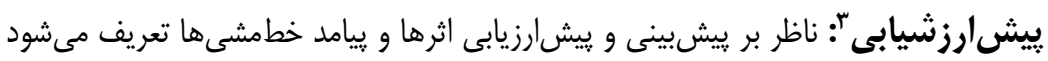
و هدف آن تزريق اطلاعات به فرايند تصميمگيرى است. ييشارزشيابى ابزارى است براى انتخاب

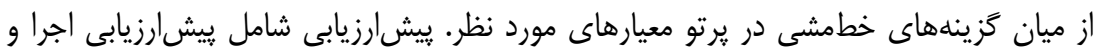
اثرهاى محيطى است؛ يعنى بتوان با تمركز بر فرايند اجرا، ابزارهاى مناسب اجرايى را ارزيابى كرد

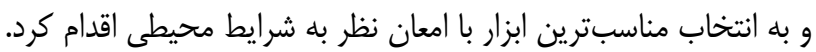
ارزشيابى مستمرع: ناظر بر تشخيص اثرها و نتايج مقياسها و برنامههاى خطمشى است

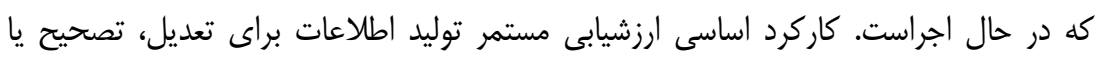
بازهدايت فرايند اجرا يا حتى تصميمهاى زيربنايى خطمشى است. يايش را مىتوان به عنوان يكى إنى رويه ارزشيابى مستمر بهشمار آورد كه هدف آن تشخيص اثرهاى فعاليتهاى مستمر است. انتخاب شاخصهاى عملكرد مناسب، عامل كليدى در يايش است.

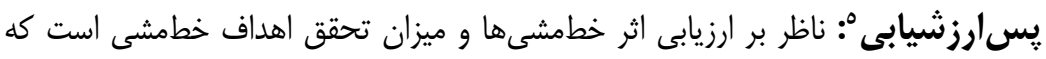

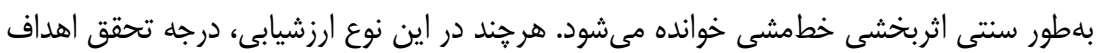

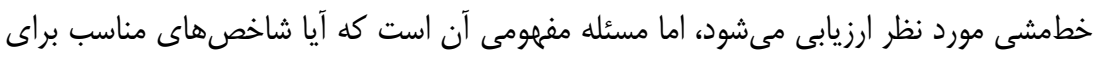

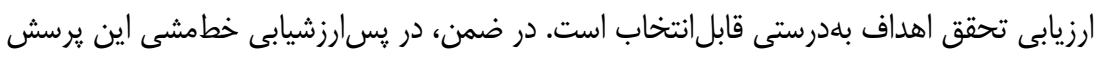

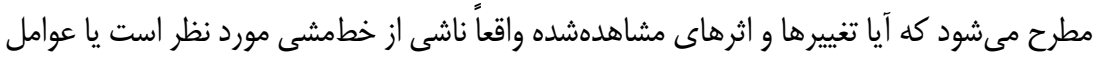
علّى ديخرى در تركيب با خطمشى مورد نظر هنين اثرهايى را به بار مى آورند؟

1. Scriven

2. Wollmann

3. Ex-Ante Evaluation

4. Ongoing Evaluation

5. Ex-Post Evaluation 
فرارزشيابى': ناظر بر تحليل ارزشيابىهاى انجامشده ييشين است كه با استفاده از دادهاى ثانويه

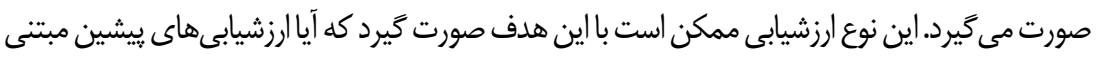

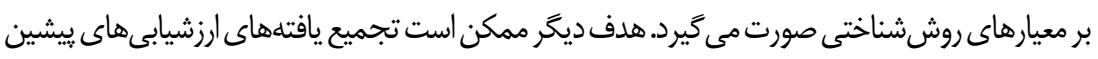

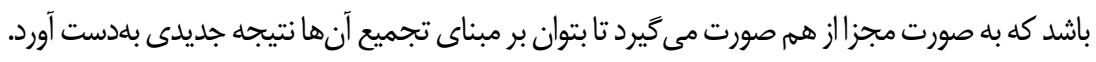

\section{معيارهاى ارزشيابى خطمشى}

در خصوص ارزشيابى خطمشى، معيارهاى بلهنبت متفاوتى مطرح است كه معروفترين آنها

تشريح مىشود.

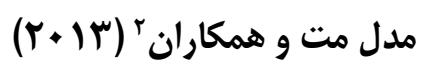

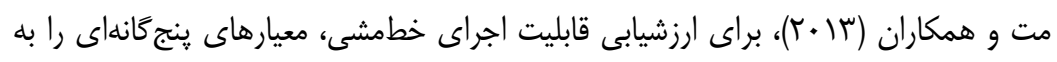
شرح جدول (سّ) ييشنهاد مى كنند.

جدول r: معيارهاى ارزشيابى قابليت اجراى خطمشى (Matt et al., 2013)

\begin{tabular}{|c|c|c|}
\hline 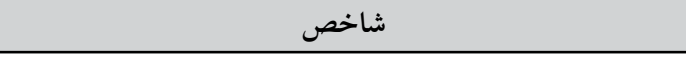 & 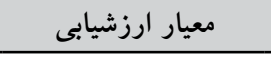 & 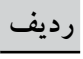 \\
\hline 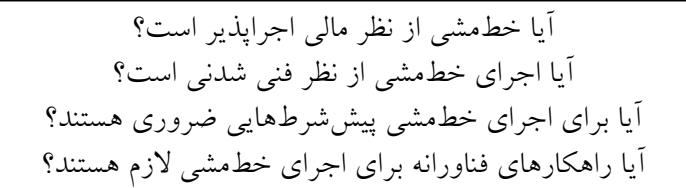 & |مكانيذيرى & 1 \\
\hline 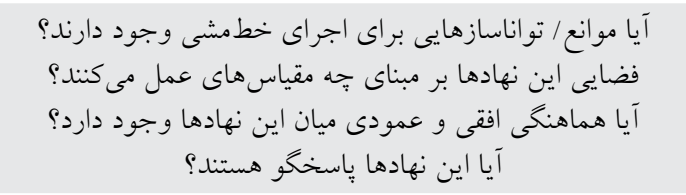 & تنظيمات نهادى & r \\
\hline 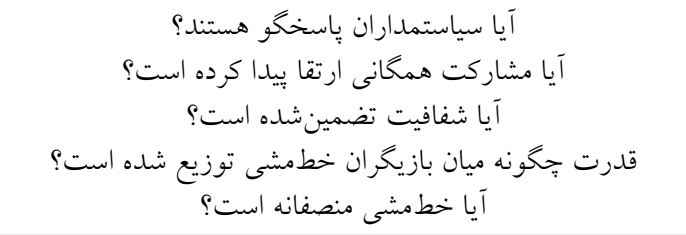 & مشروعيت سياسى & r \\
\hline آيا ابزار اجراى خطمشى از سوى عموم مردم يذيرفتهشده است؟ & قابليت پِيرش اجتماعى & r \\
\hline
\end{tabular}

2. Matt et al. 
ادامه جدول "َ: معيارهاى ارزشيابى قابليت اجراى خطمشى (Matt et al., 2013)

\begin{tabular}{|c|c|c|}
\hline شاخص & معيار ارزشيابى & رديف \\
\hline 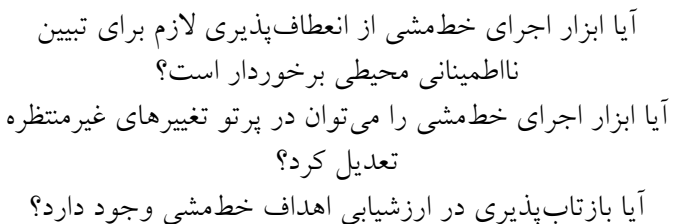 & انعطاف يذيرى & 0 \\
\hline
\end{tabular}

دان (ها +r)، شش معيار براى ارزشيابى خطمشى ييشنهاد مى كند، كه يرسشها و معيارهاى توصيفى آن در جدول (أ) كَارش مى آنود.

جدول ^ا: مقياسها و معيارهاى ارزشيابى خطمشى از ديدكاه (Dunn, 2015)

\begin{tabular}{|c|c|c|}
\hline معيارها & برسشها & مدلها \\
\hline و احدهاى خدمات & آيا نتيجه ارزشمندى بهدست آمده است؟ & \\
\hline هزينه و احد، مزاياى خالص، نسبت & براى رسيدن به يكى نتيجه ارزشمند جِقدر تلاش & كارايى׳ \\
\hline هزينه ثابت (مسئله ()، اثربخشى ثابت & تا جِه حد نيل به بيامد ارزشمند، مسئله را حل كرده & 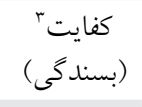 \\
\hline معيار يرتوه، معيار كالدور هيكز ؛? معيار & 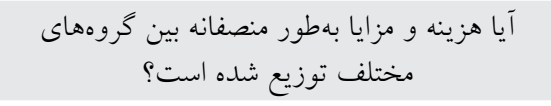 & (برابرى) \\
\hline ساز كارى با ييمايش شهروندان & 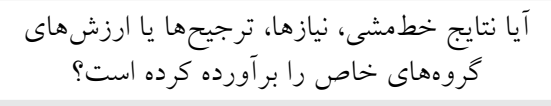 & 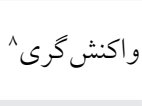 \\
\hline برنامه عمومى بايد عادلانه و كارامد & آيا بيامدهاى مطلوب (اهداف) مورد نظر ارزشمند & \\
\hline
\end{tabular}

1. Effectivenss

2. Efficiency

3. Adequacy

4. Equity

5. Pareto

6. Kaldor-Hicks

7. Rawls

8. Responsiveness 


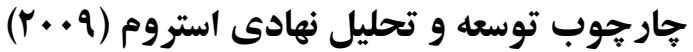

جارجوب توسعه و تحليل نهادى' در بيى درى نحوه عمل نهادها و تغيير آنها در كذر زمان

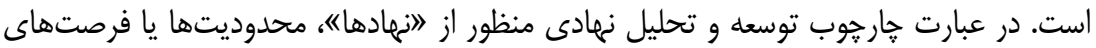
ساخت انسان است. اين خارجوب نوعى نقشه مفهومى خندلايه است كه بيان مى كند با توجه به

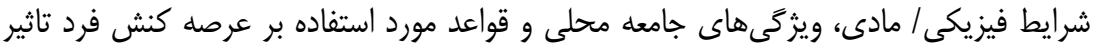

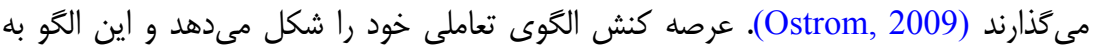

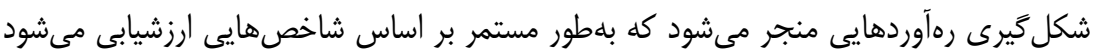

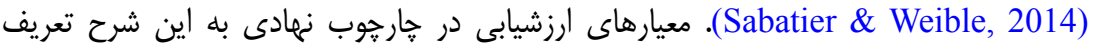

كارايى اقتصادى ؟ّ: كارايى اقتصادى بر اساس حجم تغيير در جريان مزاياى خالص مرتبط با

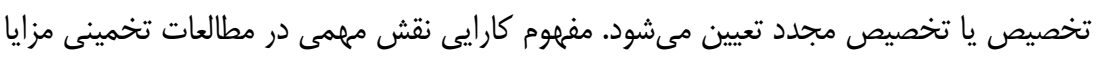

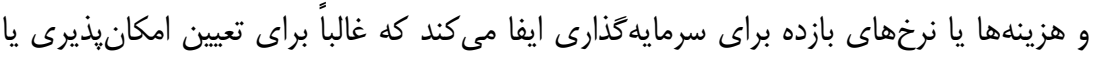

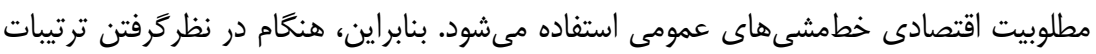

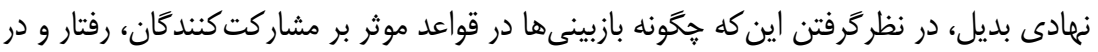
نتيجه، تخصيص منابع را تغيير مىدهد، امرى بسيار كليدى است. كارايى يعنى انجام كار درست، كه حاصل شاخصهاى درونى سازمان و نسبت ستاندهها به نهادههاست. عدالت از طريق تناظر مالى": دو ابزار اصلى براى ارزيابى عدالت وجود دارد: يكى بر

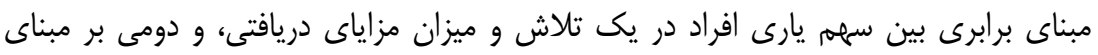
توانايىهاى تفاضلى يرداخت. مفهوم عدالت كه زيربناى اقتصاد مبادلهاى است، مدعى است كسانى دينى

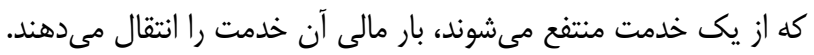
عدالت باز توزيعى داراى اهميت هستند. در نتيجه، احرجه كارايى مىتواند اين نكته را تبيين كند كه منابع كمياب در

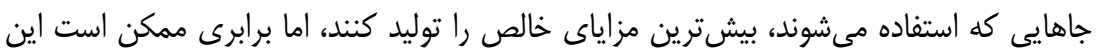
هدف را مخدوش سازد؛ زيرا نتيجه تدارك امكانات و تسهيلاتى است كه نياز هاى گروههاى نيازمند

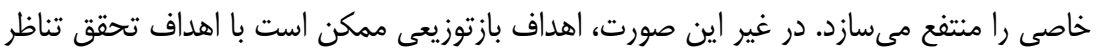

1. Institutional Analysis and Development Framework

2. Economic Efficiency

3. Fiscal Equivalence

4. Redistributional Equity 
مالى در تضاد باشد.

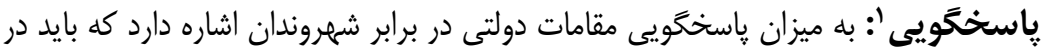
جهت توسعه و استفاده از امكانات، تسهيلات، و منافع عمومى ياسخخً باشند. در حقيقت، تحقق كارايى ايجاب مى كند كه اطلاعات در مورد ترجيحهاى شهروندان در اختيار تصميمگيرندگًان باشد تا پاسخگويى را تحقق بخشد. ترتيبات نهادى كه بلهور اثربخش اين اطلاعات را تجميع مى كند، در تحقق كارايى همزمان با افزايش در ياسخگويى و ارتقاى موفقيت اهداف بازتوزيعى نقش ايفا

همسازى با اصول اخلاق عمومى ؟ّ يزوهشگر ممكن است بخواهد سطح اصول اخلاقى ايجادشده (توسعهيافته) را به وسيله مجموعه خاصى از ترتيبات نهادى ارزشيابى كند. آيا كسانى

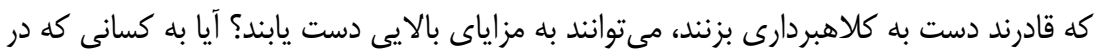
كارراهه خود اصول اخلاقى را حفظ مى كنند ياداش داده مىشود و ارتقا مىيابند؟ جَّونه افرادى

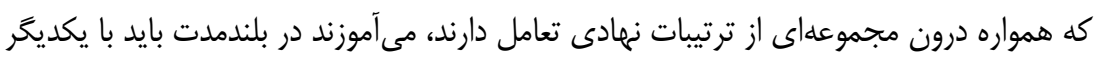
ارتباط برقرار كنند؟ - ماه

قابليت انطباق يذيرى بّ: تا زمانى كه ترتيبات نهادى قادر به واكنش با محيطهاى متلاطهم

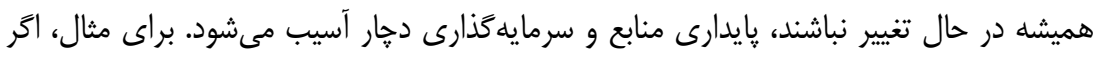
يك سيستم آبيارى به صورت متمركز كتترل شود و فقط حجم خاصى از منابع را براى نكَهدارى سالانه و دورهاى تخصيص دهد، ممكن است قادر به تحقق نيازهاى خاص مرتبط با سيل عظيمى بهى كه بخشى از سيستم كانال را تخريب مى كند، نباشد (Sabatier, 1991). همانطور كه ديده مىشود، اختلافنظر قابلتوجهى بين انديشمندان از نظر معيارهاى ارزشيابى خطمشى وجود دارد. اين اختلافنظر ناشى از رويكرد يا هار هوب متفاوتى است كه انديشمندان خطمشى گذارى انتخاب

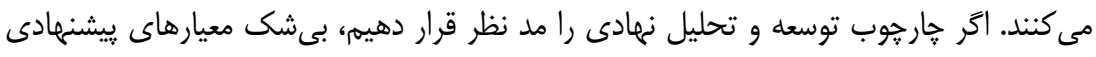

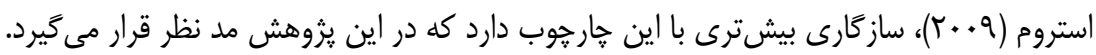

\section{خطمشى شراكت عمومى - خصوصى در ايران}

در ايران شراكت عمومى ـ خصوصى داراى جالشهاى بزرگى است. قوانين و مقررات كشور ايران نواقص زيادى در زمينه شراكت عمومى ـ خصوصى بلهوجود آورده است. در كشورهاى

1. Accountability

2. Conformance to General Morality

3. Adaptability 
توسعهيافته قوانين ترغيبى و تشويقى بسيارى براى بخش خصوصى فراهم است؛ اما در كشور

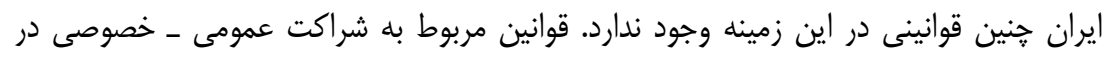
ايران بسيار براكنده و كلى است. همجنين، خطمشى واحدى براى شراكت عمومى ـ خصوصى در ايران وجود ندارد. نياز به توضيح است كه در سال يوجا دولت يازدهم لايحه منسجمى را تحت عنوان مشاركت عمومى ـ خصوصى تهيه و براى تصويب نهايى به مجلس شوراى اسلامى ارائه

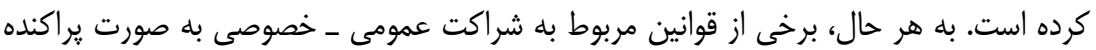

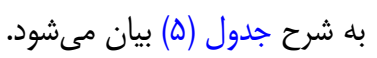

جدول ه: اسناد بالادستى ناظر بر خطمشى شراكت عمومى ـ خصوصى

\begin{tabular}{|c|c|}
\hline 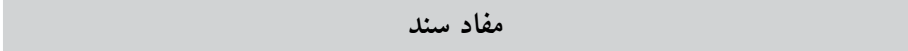 & 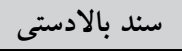 \\
\hline 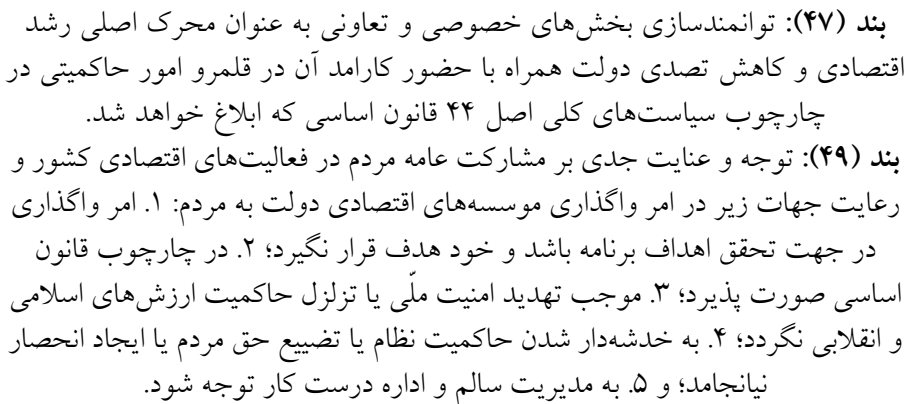 & سند جشم انداز \\
\hline بند 19: زمينهسازى براى جذب و استفاده از ظرفيتهاى مردمى در نظام ادارى. & 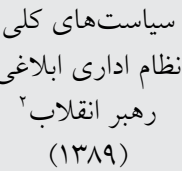 \\
\hline
\end{tabular}

1. http://www.maslahat.ir/index.jsp?fkeyid=\&siteid=3\&pageid=797

2. http://www.maslahat.ir/index.jsp?siteid=3\&fkeyid=\&siteid=3\&pageid=575 
ادامه جدول ه: اسناد بالادستى ناظر بر خطمشى شراكت عمومى ـ خصوصى

\section{مفاد سند}

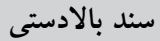

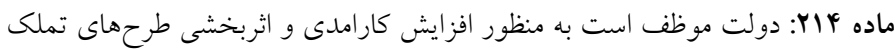

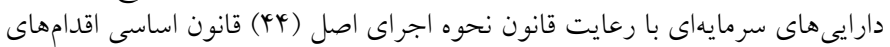

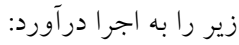

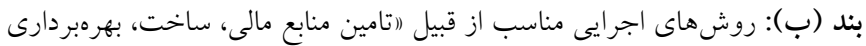

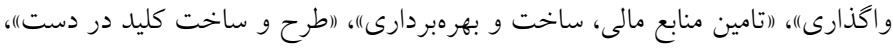

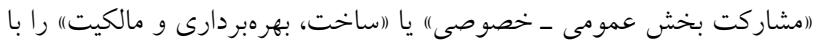

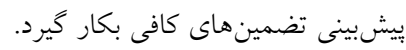

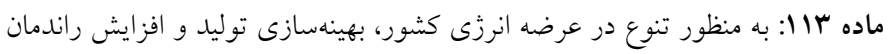

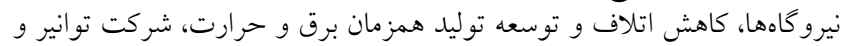

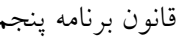

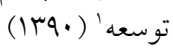

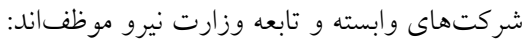

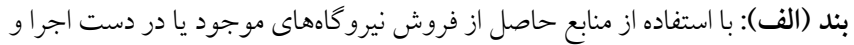

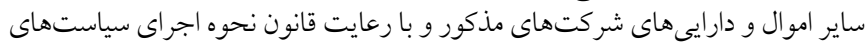

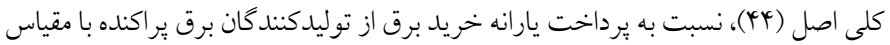

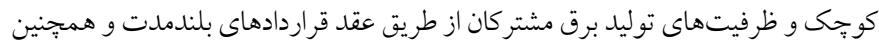

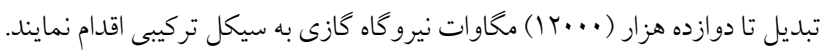

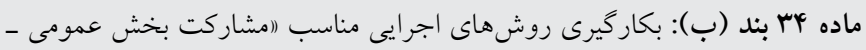

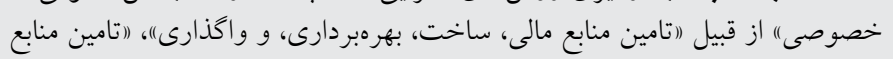

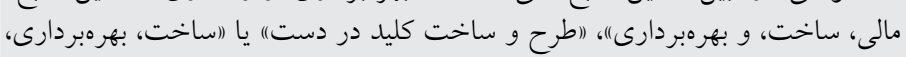

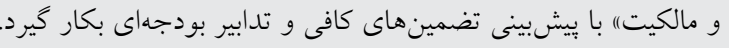

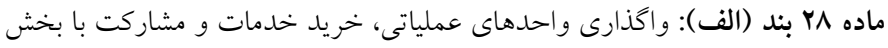

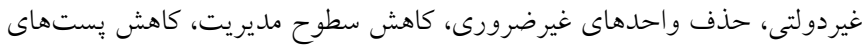

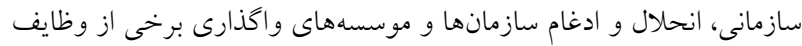

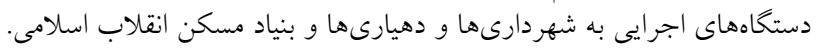

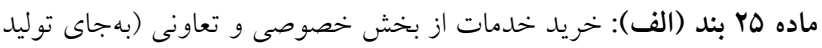

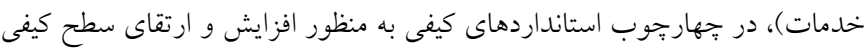

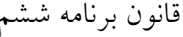

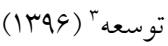
خدمات و مديريت بهينه هزينه. ماده VV: استفاده از سرمايه گذارى بخش خصو درازاى واگذارى يساب استحصالى.

1. https://rc.majlis.ir/fa/law/show/790196

2. https://rc.majlis.ir/fa/law/show/790196

3. https://rc.majlis.ir/fa/law/show/790196 


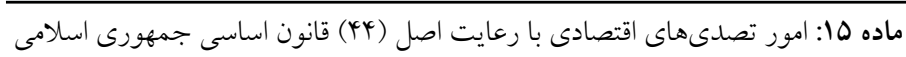

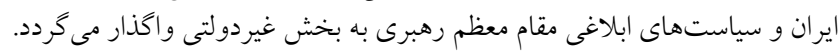

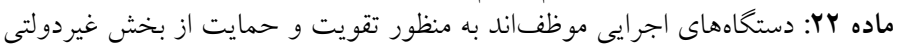

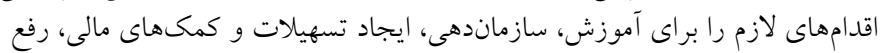

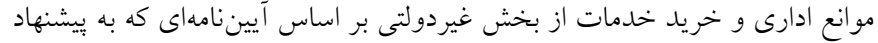

همان طور كه در جدول (ه) ديده مىشود، خطمشى شراكت عمومى ـ خصوصى در ايران در

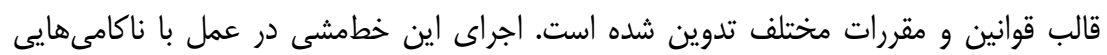
مواجه است كه نياز است با ارزشيابى ادوارى براى اصلاح و بهبود آن اقدام شود.

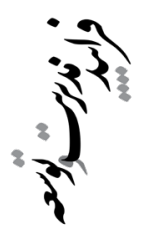

\section{يرسش هاى يخوهش}

با توجه به هارجوب توسعه و تحليل نهادى، برسشهاى اصلى و فرعى به شرح زير قابلطرح

\section{يرسش اصلى}

- اثربخشى خطمشى شراكت عمومى ـ خصوصى در سازمانهاى عمومى ايران در خه سطحى

\section{يرسش انشاى فرعى}

- اثربخشى خطمشى شراكت عمومى ـ خصوصى در سازمانهاى عمومى از نظر كارايى

اقتصادى در هيه سطحى است؟

- اثربخشى خطمشى شراكت عمومى ـ خصوصى در سازمانهاى عمومى از نظر عدالت مالى سلى

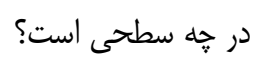

- اثربخشى خطمشى شراكت عمومى ـ خصوصى در سازمانهاى عمومى از نظر عدالت

$$
\text { بازتوزيعى در خه سطحى است؟ }
$$

- اثربخشى خطمشى شراكت عمومى ـ خصوصى در سازمانهاى انمان عمومى از نظر قابليت

$$
\text { انطباقيذيرى در خه سطحى است؟ خطمش شراك }
$$


- اثربخشى خطمشى شراكت عمومى ـ خصوصى در سازمانهاى عمومى از نظر همسازى با

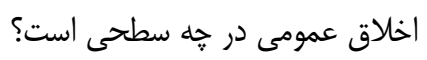

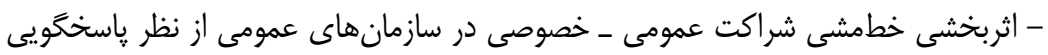

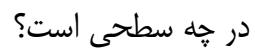

\section{روش}

بر اساس مدل يياز يزوهش (Saunders et al., 2009)، اين يزوهش از نوع كاربردى،

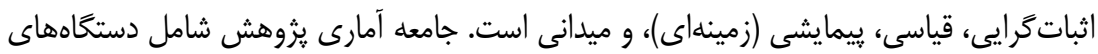
اجرايى در بخش عمومى است كه متولى اجراى خطمشى شراكت عمومى ـ خصوصى هستند كه إنى

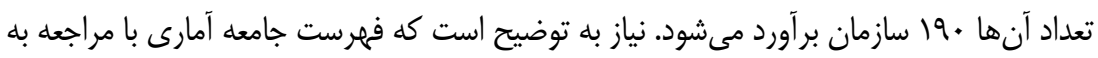

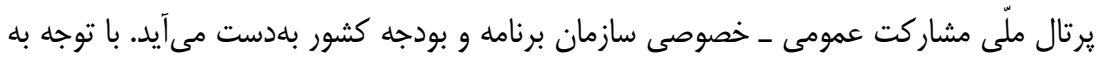

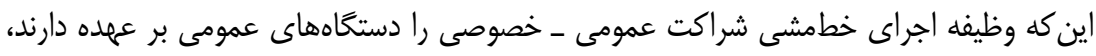

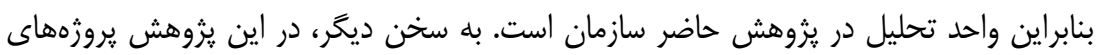

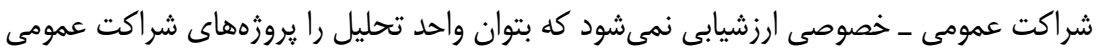

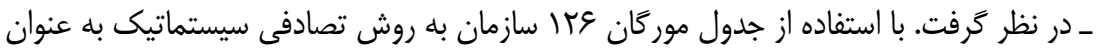

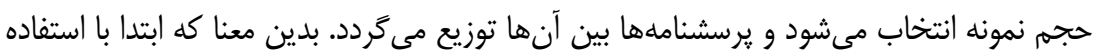

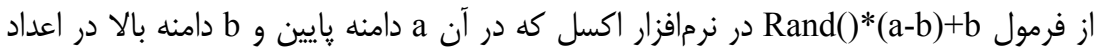
تصادفى است، وץا عدد تصادفى از ميان •19 عدد انتخاب مىشود و با در نظركرفتن شماره

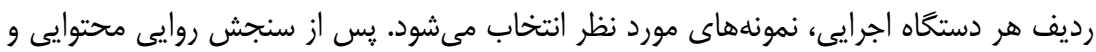

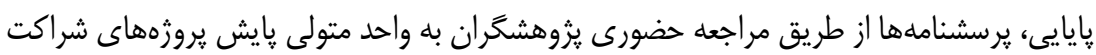

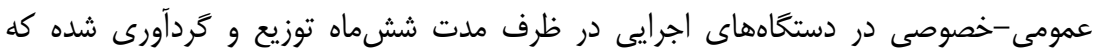
خوشبختانه تمامى يرسشنامهاى توزيعشده بلدرستى تكميل شدهاند.

\section{سنجش متغير ها}

در اين يزوهش از معيارهاى ششكانه هاريوب تحليل نهادى (Ostrom, 2009)، براى ارزشيابى خطمشى عمومى شراكت عمومى ـ خصوصى استفاده مىشود. نماكر هاى مورد استفاده براى سنجش اين متغيرها به شرح جدول (و) است. 
جدول \&: نماكرهاى مرتبط با معيارهاى اثربخشى خطمشى شراكت عمومى ـ خصوصى

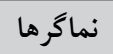

متغير

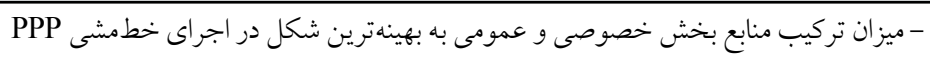

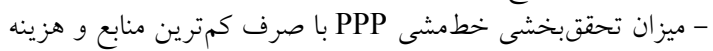

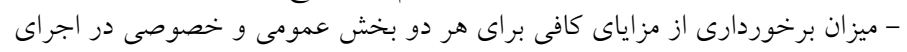

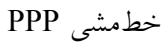
كارايى اقتصادى

PPP ميزان استفاده بهينه از ظرفيت بخش خصوصى در اجراى خطمشى -

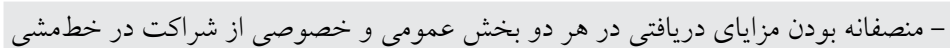
PPP

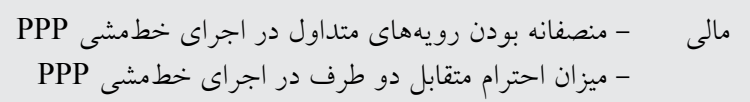

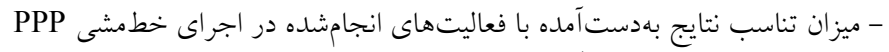

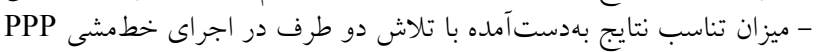

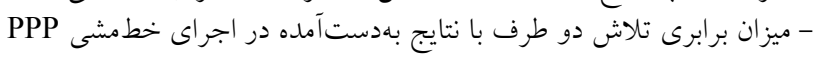
عدالت कर

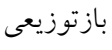

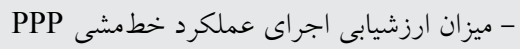

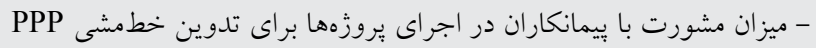

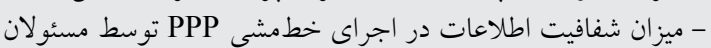
ياسخخويى

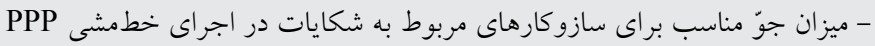

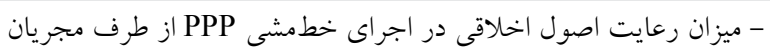

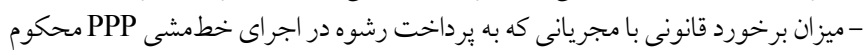
مىشوند

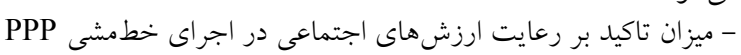
همسازى با اخلاق عمومى بالخلاق

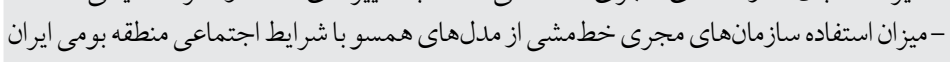

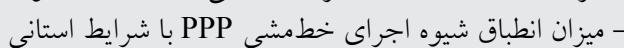
|نطباقيذيرى

\section{روايى و هايايى ثرسشنامه}

مقصود از روايى آن است كه ابزار سنجش بتواند خصيصه مورد نظر را اندازهگيرى كند، نه

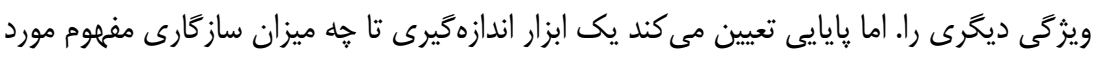
نظر را اندازه مى ئيرد (Saunders et al., 2009). براى روايى يرسشنامه با توجه به كسب روايى

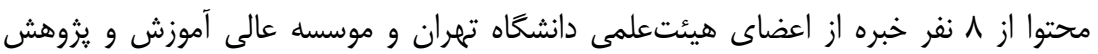


مديريت و برنامهريزى استفاده مىشود كه نشان مىدهد نسبت روايى محتوا (CVR)'، براى هر

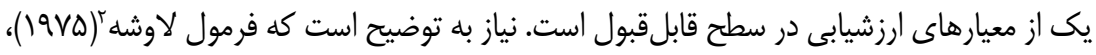

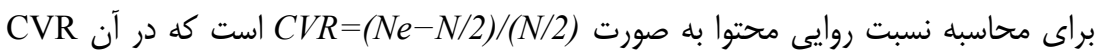
نسبت روايى محتوا، Ne تعداد ارزيابان است كه بيان مىدارند كويه مورد نظر اساسى يا سودمند

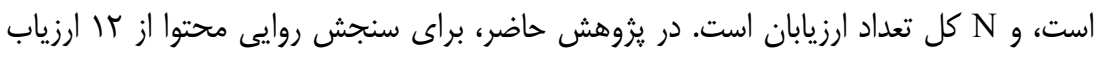
استفاده مىشود و 9 نفر كويههاى يرسشنامه را اساسى يا سودمند ارزيابى مى كنند و مقدار نسبت

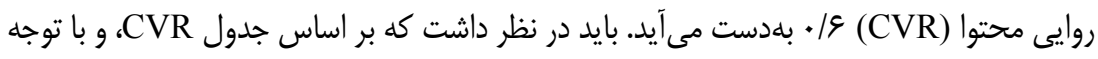

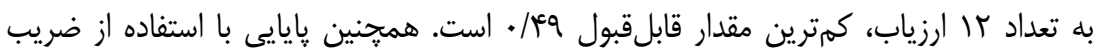
آلفاى كرونباخ محاسبه مىشود كه روشى براى محاسبه هماهنگى درونى ابزار اندازمخيرى از جمله

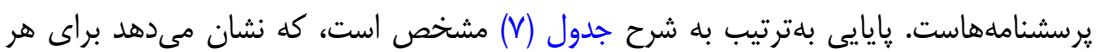
يك از اين ابعاد اشارهشده بيشتر از V/• است و نشان از يايايى مناسب اين ابعاد دارد. نياز به اشاره

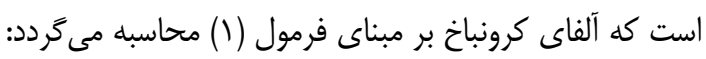

$r_{\alpha}=\frac{J}{J-1}\left(1-\frac{\sum S_{j}^{2}}{S^{2}}\right)$

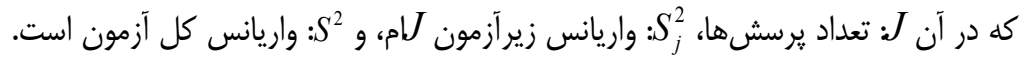

جدول У: اعتبار و روايى يرسشنامه

\begin{tabular}{|c|c|c|c|}
\hline نسبت روايى محتوايى & آلفاى ثانويه & آلفاى اوليه & 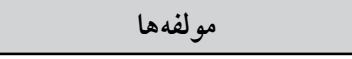 \\
\hline$\cdot / 9 \pi$ & $\cdot / \wedge$ & $\cdot / 91$ & كارايى اقتصادى \\
\hline$\cdot / \Lambda r$ & $\therefore / \mathrm{Aq}$ & $\cdot / \Lambda Y^{4}$ & 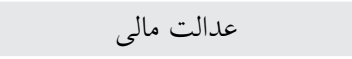 \\
\hline$\cdot / V Q$ & $\cdot|\wedge|$ & $\cdot / \mathrm{Vq}$ & عدالت بازتوزيعى \\
\hline$\cdot|\wedge|$ & $\cdot / v$ & $\cdot / \mathrm{Va}$ & ياسخكويى \\
\hline$\cdot / \Lambda r$ & $\cdot / \Lambda \mu$ & $\cdot / M$ & همسازى با اصول اخلاق عمومى \\
\hline.$/ 91$ & $\cdot / \wedge Q$ & $\cdot / \Lambda \mathrm{V}$ & قابليت انطباقيذيرى \\
\hline
\end{tabular}

1. Content Validity Ratio

2. Lawshe 


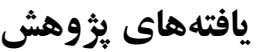

آمارهاى توصيفى معيارهاى ششكانه ارزشيابى خطمشى شراكت عمومى ـ خصوصى با

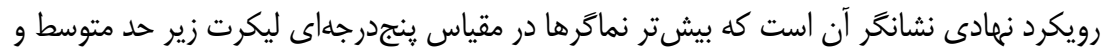

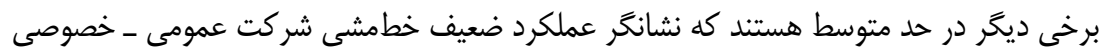

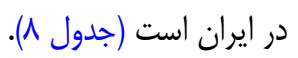

\begin{tabular}{|c|c|c|c|c|c|c|}
\hline استحراف إندارد & ميانغين & بيشينه & كمينه & 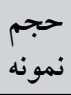 & 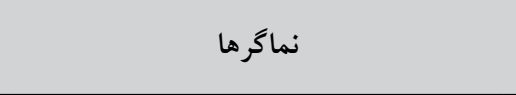 & معيار \\
\hline$\cdot / 9 T$ & T/QV & 0 & 1 & 1KG & 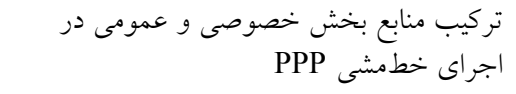 & \\
\hline$\cdot / 91$ & $r / Q V$ & Q & 1 & 1KG & تحقق بخشى يروزههاى PPP با صرف كمترين & كارايى . \\
\hline.$/ 90$ & T/AY & $\Delta$ & 1 & IrG & 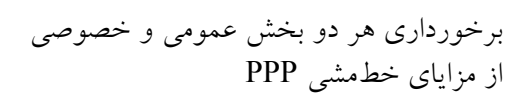 & 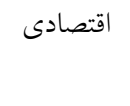 \\
\hline $1 / \cdot r$ & $r / v \cdot$ & 0 & 1 & ITE & 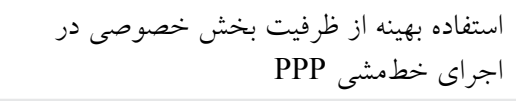 & \\
\hline$\cdot / 9 V$ & $r / \Lambda I$ & Q & 1 & IKG & 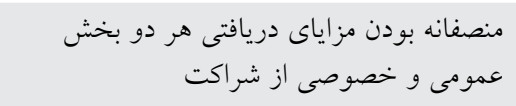 & \\
\hline$\cdot / 9 V$ & T/AY & 0 & 1 & 1149 & $\begin{array}{r}\text { خطمشى منصفانه بودن رويههاى متداول در اجراى } \\
\text { PPP }\end{array}$ & عد الت مالى \\
\hline$\cdot / 94$ & $r / \uparrow \Lambda$ & $\Delta$ & 1 & lre & احترام متقابل دو طرف در اجراى خطمشى PPP & \\
\hline$\cdot / A \mid$ & $r / \cdot r$ & 0 & 1 & 1149 & 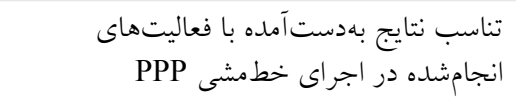 & \\
\hline •/AT & $r / \cdot \varphi^{c}$ & 0 & 1 & 1149 & 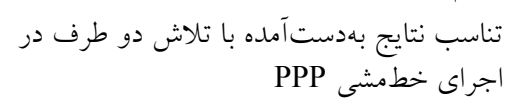 & بازتوزيعى عدالت \\
\hline$\cdot / \Lambda T$ & $r / A V$ & $\Delta$ & 1 & 1149 & برابرى تلاش دو طرف با نتايج بهدست آمده در & \\
\hline
\end{tabular}

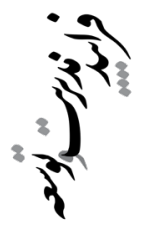




\begin{tabular}{|c|c|c|c|c|c|}
\hline انحتاف اندارد & ميانگين & بينه & كمينه & 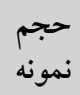 & نماكر ها \\
\hline$\cdot / \mathrm{M}$ & T/VG & 0 & 1 & 1K9 & ارزشيابى اجراى عملكرد خطمشى PPP \\
\hline $1 / \cdot 1$ & r/Q & 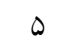 & 1 & 1re & مشورت با بيمانكاران در اجراى خطمشى PPP \\
\hline $1 / \cdot V$ & T/QT & 0 & 1 & $1 \% 9$ & ياسخكويى شفافيف اطلاعات در اجراى خطمشى PPP \\
\hline$\cdot / 9 T$ & $r / N$ & $\Delta$ & 1 & $1 \% 9$ & 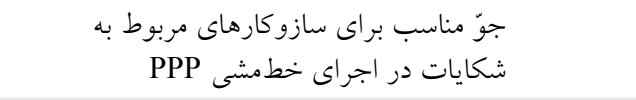 \\
\hline$\cdot / 99$ & $r / \bullet \wedge$ & 0 & 1 & $1 \% 4$ & طرف مجريان اصول اخلاقى در اجراى خطمشى از \\
\hline $1 / \pi r$ & r/Ar & 0 & 1 & 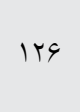 & 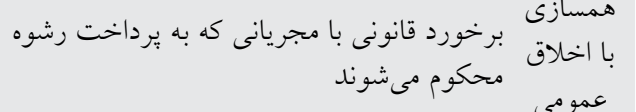 \\
\hline $1 / \cdot 0$ & $r / \wedge 9$ & Q & 1 & 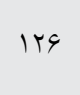 & $\begin{array}{r}\text { خطيد بر رعايت ارزشى هPاى اجتماعى در اجراى } \\
\text { PPP }\end{array}$ \\
\hline .199 & $r / 94$ & 0 & 1 & $1 \% 4$ & 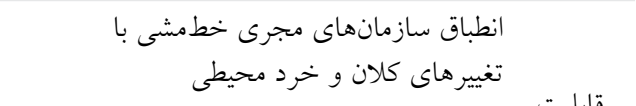 \\
\hline$\cdot / 9 r$ & T/q & 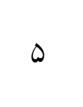 & 1 & $1 \% 4$ & انطباقيذيرى شريط استفاده مجريان خطمشى از مدلهاى همسو با \\
\hline$\cdot / 94$ & TNO & 0 & 1 & 1T4 & انطباق شيوه اجر اى خطمشى PPP باشر ايط استانى \\
\hline
\end{tabular}

تعميم يافتههاى مبتنى بر نمونه به كل جامعه، مستلزم بكارگيرى t تكنمونهاى است. زيرا يثروهشَر به دنبال آن است كه بداند آيا ميانگين يك متغير از حدود خاصى (ميانگين مفروض)

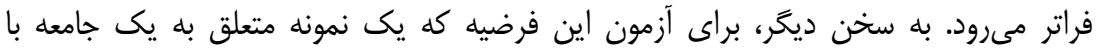
ميانخين مشخص اما انحراف معيار نامشخص است، از آمارة t استفاده مىشود. براى سنجش اين كه معيارهاى اثربخشى خطمشى شراكت عمومى ـ خصوصى در سطح مطلوبى هستند، ضرورى است

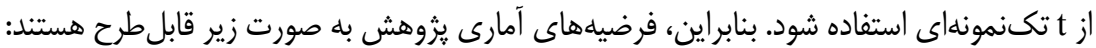

معيارهاى اثربخشى خطمشى شراكت عمومى ـ خصوصى در سطح مطلوب نيستند. براى آزمون فرضيه آمارى، بعد از بررسى نرمال بودن متغيرها، از توزيع t تكنمونهاى استفاده مىشود كه نتايج آن در جدول (9) منعكس است. 
جدول 9: آزمون t تكنمونهاى براى سنجش اثربخشى خطمشى شراكت عمومى ـ خصوصى

$$
\text { ارزش آزمون }
$$

\begin{tabular}{|c|c|c|c|c|c|c|}
\hline \multicolumn{2}{|c|}{ فاصله اطمينان ها درصد } & \multirow{2}{*}{ 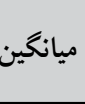 } & \multirow{2}{*}{ معنادارى } & \multirow{2}{*}{ آزادى درجه } & \multirow{2}{*}{ مقدار t } & \multirow{2}{*}{ معيارهاى اثربخشى خطمشى } \\
\hline 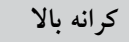 & كرانه يايين & & & & & \\
\hline$-\cdot / 19$ & $-\cdot / 44$ & $r / 9 V$ & $\cdot \cdots$ & Iro & $-Y / V Q$ & كارايى اقتصادى \\
\hline$-\cdot / \cdot \wedge$ & $-\cdot / 19$ & $r / 9 Y^{4}$ & - pet & Iro & $-\cdot / \sqrt{ } 9$ & عدالت مالى \\
\hline$\cdot 11$ & $-\cdot / 14$ & $r / 9 \Lambda$ & $\cdot / 1 \cdot 1$ & ITO & $-\cdot / r \Delta$ & عدالت بازتوزيعى \\
\hline$-\cdot / r$ & $-\cdot / \uparrow \wedge$ & $r / 94$ & $\bullet \cdots$ & Iro & $-Q / 9 V$ & ياسخخويى \\
\hline$\cdot / 11$ & $-\cdot / T r$ & $r / 94$ & $\cdot / 014$ & ITD & -.190 & همسازى با اصول اخلاق عمومى \\
\hline$-\cdot / I V$ &.$- / 44$ & $r / 9 V$ & $\cdot \cdots$ & ITO & $-k / 4 r$ & قابليت انطباقيذيرى \\
\hline
\end{tabular}

همان طور كه در جدول (9) ديده مىشود، با توجه به منفى بودن مقدار t، و با محاسبه سطح معنادارى يك دامنه كه مقدار آن بزرگتر از هـ/• مىشود، در فاصله اطمينان هو درصد نمىتوان فرض صفر را رد كرد. به سخن ديخر، خطمشى شراكت عمومى ـ خصوصى از نظر معيارهاى كارايى اقتصادى، عدالت مالى، عدالت بازتوزيعى، پاسخگُويى، همسازى با اخلاق عمومى، و قابليت

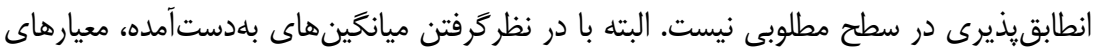
اثربخشى در سطح يكسانى قرار ندارند كه در شكل (1) زير مشخص است.
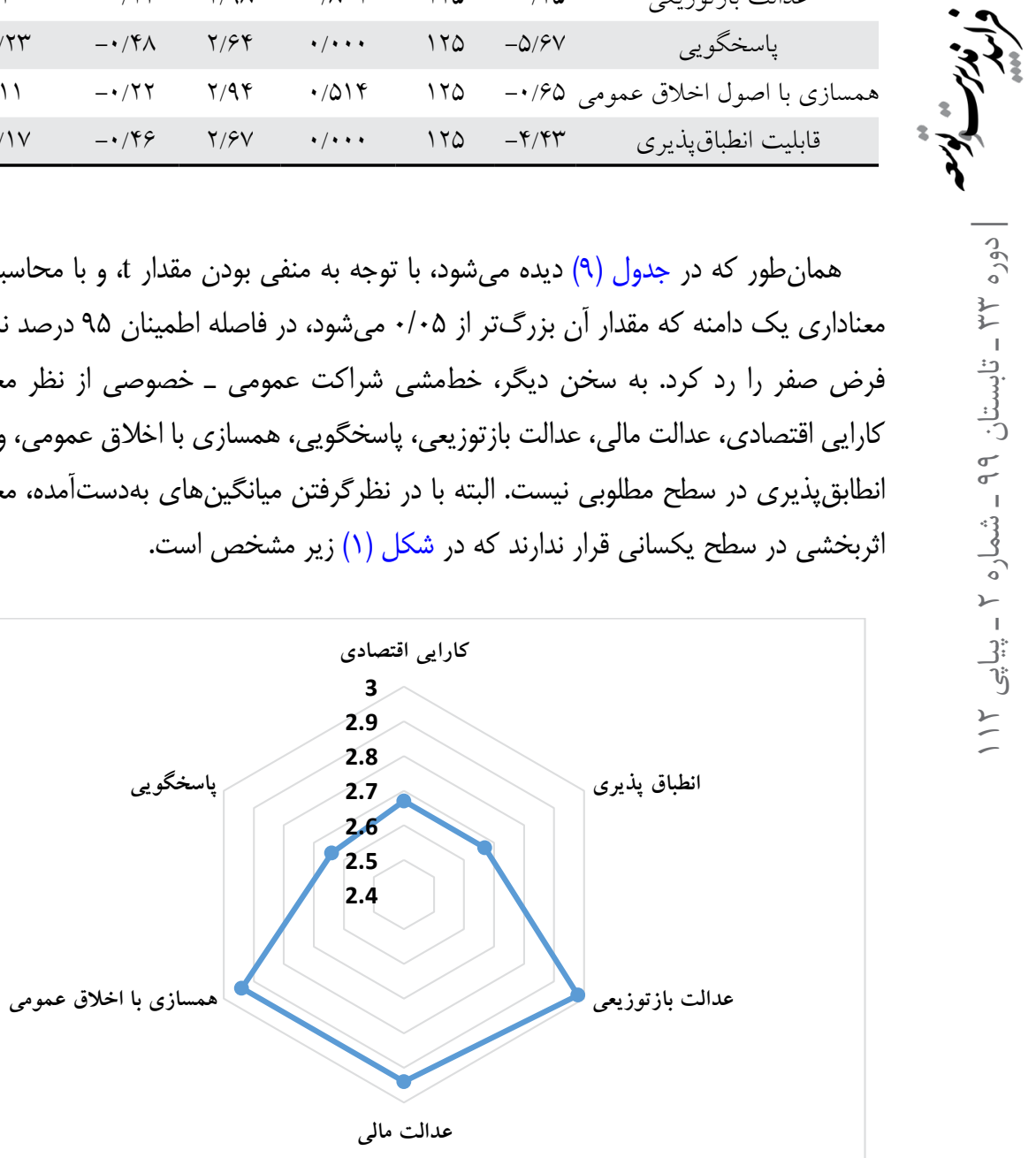

شكل ا: نمودار تارعنكبوتى معيارهاى اثربخشى خطمشى شراكت عمومى ـ خصوصى 
همانطور كه در شكل (1) ديده، خطمشى شراكت عمومى ـ خصوصى در سازمانهاى عمومى

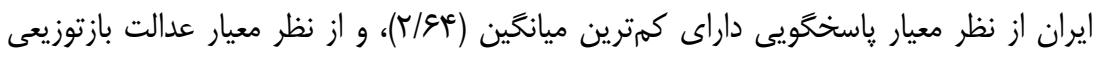

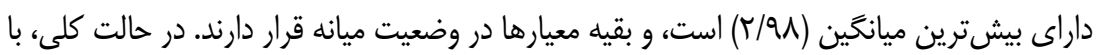

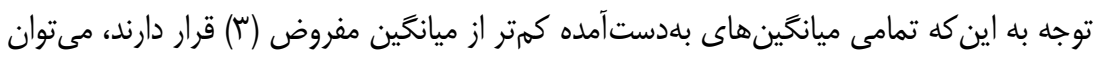

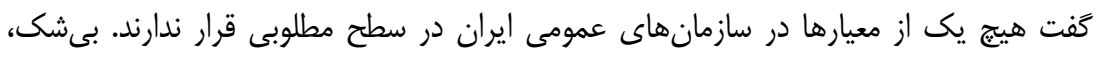

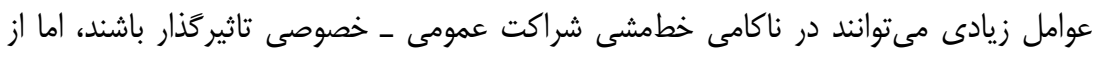

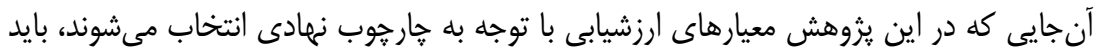

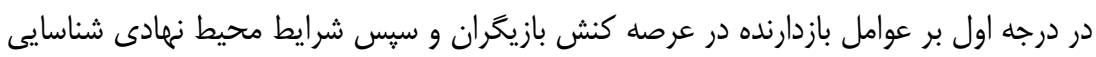
و اولويتبندى شوند.

\section{بحث و نتيجه كيرى}

امروزه، شراكت عمومى ـ خصوصى به عنوان يكى از سازوكارهاى شناختهشده در مديريت

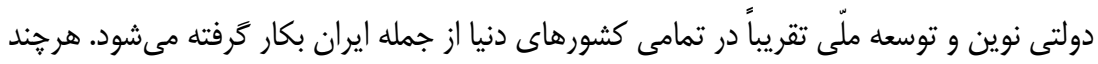

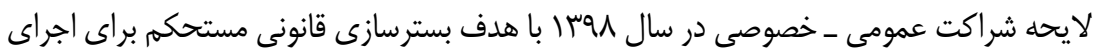

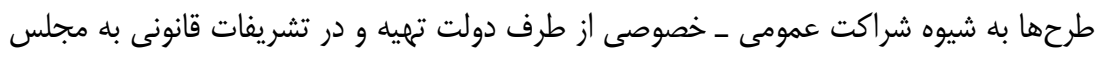

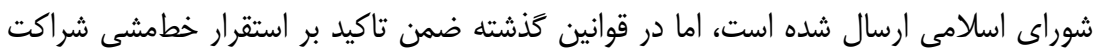

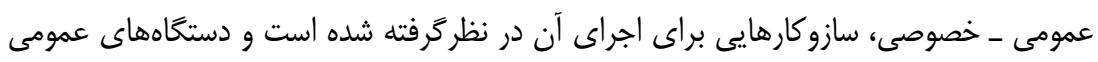

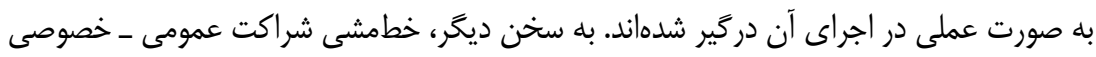

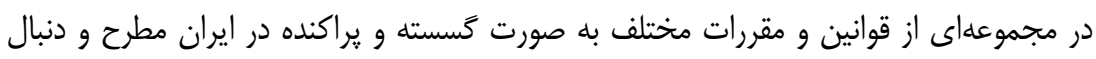

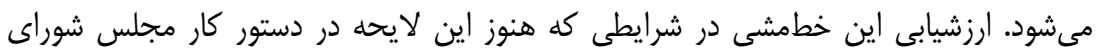

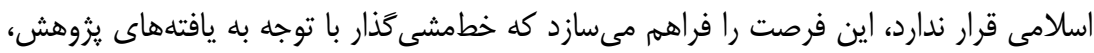

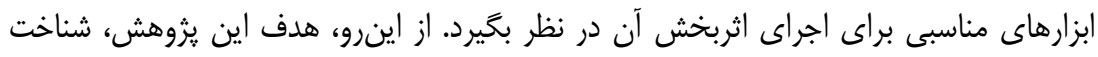

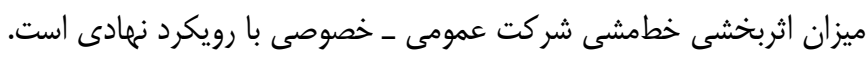

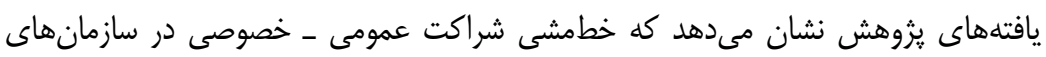

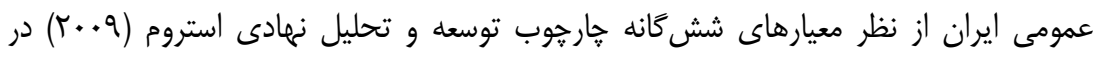

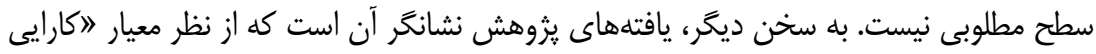
اقتصادى"، خطمشى شر كت عمومى ـ خصوصى از اثربخشى لازم برخوردار نيست. جنين يافتهاى

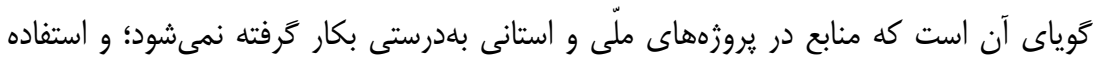


بهينهاى از ظرفيت بخش خصوصى در اجراى يروزهها به عمل نمى آيد. ارزشيابى خطمشى شراكت

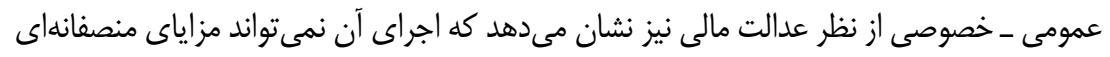

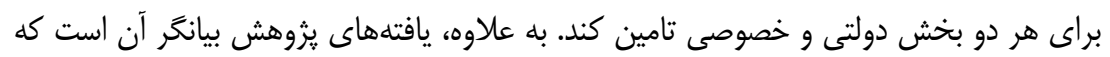

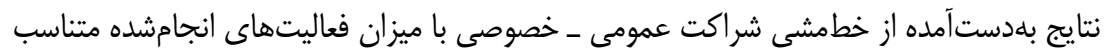

نيست (كمتوجهى به عدالت بازتوزيعى).

در ضمن، يافتهاى يزوهش نشان مىدهد كه خطمشى شراكت عمومى -خصوصى با كمترين

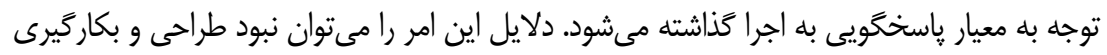

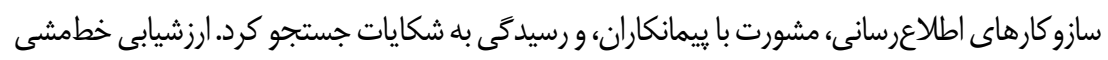

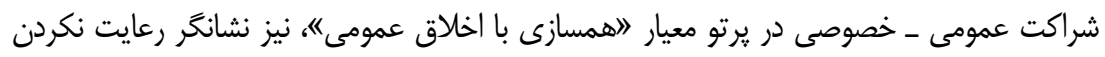

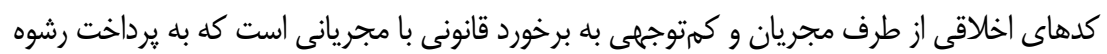
در اجراى خطمشى متوسل مىشوند. سرانجام، ارزشيابى خطمشى شراكت عمومى ـ خصوصى از نظر

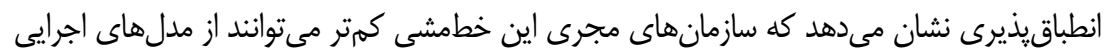

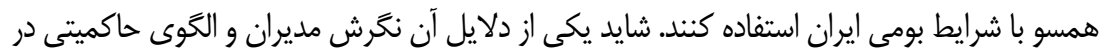

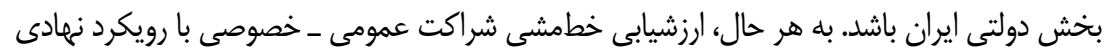

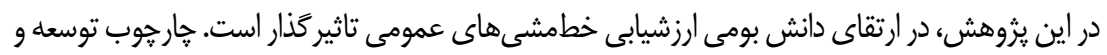
تحليل نهادى، معيارهاى بهنسبت جامعى براى ارزشيابى خطمشى هاى عمومى فراهم مى سازند و دانش رانش

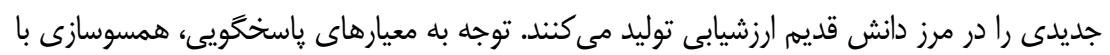
اخلاق عمومى و انطباقيذيرى، با ديدمان حاكميتى عمومى همخوانى بيشترى دارد.

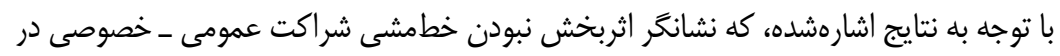

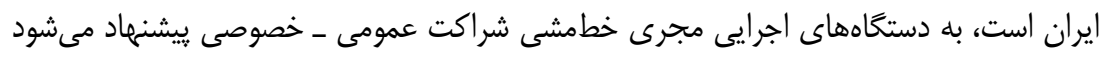

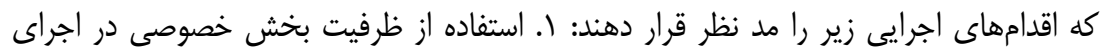
يروزههاى مختلف با عقد قرارداد بهينه؛ ז. توجه به منصفانه بودن روشهاى اجرايى بروز إههاى

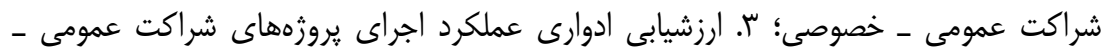
خصوصى؛ זٔ. مشورت با ييمانكاران در اجراى يروزهها؛ ه. شفافيت در اجراى يروزهها؛ 9 ت. تصريح

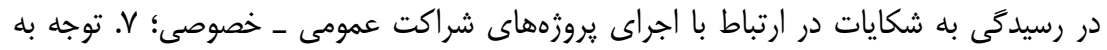

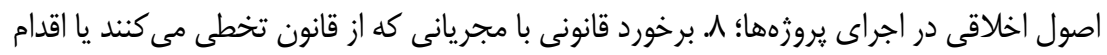

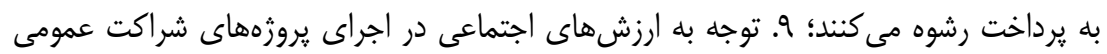

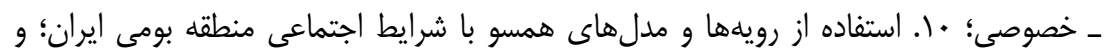


II. توجه به انطباق شيوههاى اجرايى يروزه شراكت عمومى ـ خصوصى با شرايط استانى. بىشك، هر يزوهش داراى محدوديتهاى خاص خود است. در اين يزوهش، براى براي

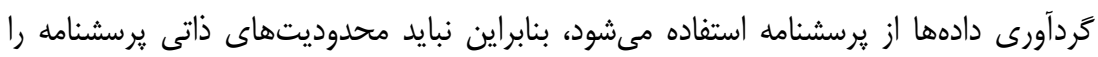

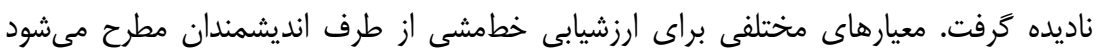

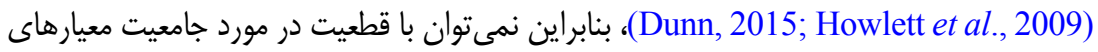
استفادهشه در ارزشيابى خطمشى شراكت عمومى-خصوصى صحبت كرد. در بايان، از آنجا كه يافتهاى يزوهش حاضر ناظر بر سازمانهاى دولتى در شهر تهران است، در خصوص تعميم آن به كل سازمانهاى دولتى در شهرهاى مختلف بايد جانب احتياط رعايت شود. با توجه به مسائل

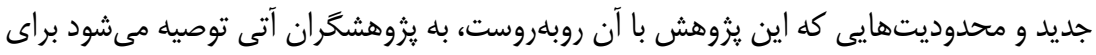
رسيدن به مدل جامع بومى در ارزشيابى خطمشىهاى عمومى، يزوهشهاى تكميلى را دنبال كنند، برائ

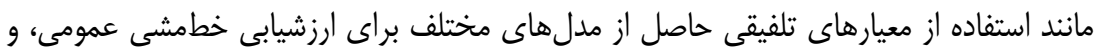
ارزشيابى خطمشى شراكت عمومى-خصوصى از ديدًاه ذى نفعان مختلف.

\section{منابع}

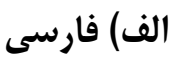

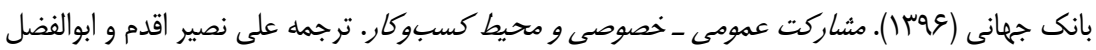

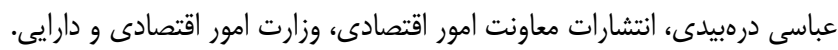

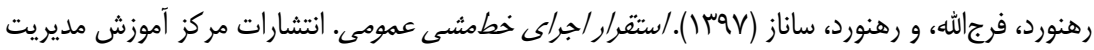
دولتى.

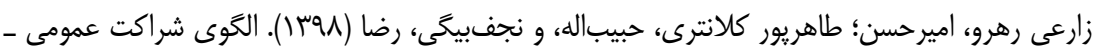

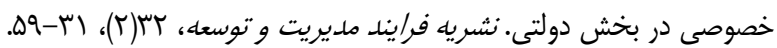

http://jmdp.ir/article-1-3349-fa.html

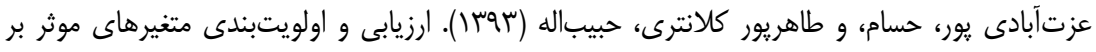

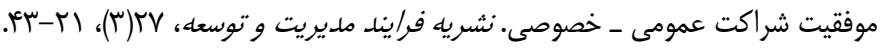
http://jmdp.ir/article-1-2146-fa.html

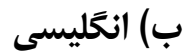

Albalate, D., \& Bel-Piñana, P. (2019). The Effects of Public Private Partnerships on Road Safety Outcomes. Accident Analysis \& Prevention, 128(1), 53-64. https://doi.org/10.1016/j.aap.2019.03.015.

Althaus, C., Bridgman, P., \& Davis, G. (2017). The Australian Policy Handbook: 
A Practical Guide to the Policy Making Process: Allen \& Unwin.

Burger, P., \& Hawkesworth, I. (2011). How to Attain Value for Money: Comparing PPP and Traditional Infrastructure Public Procurement. OECD Journal on Budgeting, 11(1), 91-146. https://doi.org/10.1787/16812336.

Dunleavy, P., Margetts, H., Bastow, S., \& Tinkler, J. (2006). New Public Management is Dead - Long Live Digital-Era Governance. Journal of Public Administration Research and Theory, 16(3), 467-494. https://doi. org/10.1093/jopart/mui057.

Dunn, W. N. (2015). Public Policy Analysis: An Integrated Approach, 5th Edition: Routledge.

Grimsey, D., \& Lewis, M. (2007). Public Private Partnerships: The Worldwide Revolution in Infrastructure Provision and Project Finance: Edward Elgar Publishing.

Grimsey, D., \& Lewis, M. K. (2002). Evaluating the Risks of Public Private Partnerships for Infrastructure Projects. International Journal of Project Management, 20(2), 107-118. https://doi.org/10.1016/S0263-7863(00)00040-5.

Hitchler, M. J., \& Domann, F. E. (2007). An Epigenetic Perspective on the Free Radical Theory of Development. Free Radical Biology and Medicine, 43(7), 1023-1036. https://doi.org/10.1016/j.freeradbiomed.2007.06.027.

Hodge, G., \& Greve, C. (2018). Contemporary Public-Private Partnership: Towards a Global Research Agenda. Financial Accountability \& Management, 34(1), 3-16. https://doi.org/10.1111/faam.12132.

Howlett, M., Ramesh, M., \& Perl, A. (2009). Studying Public Policy: Policy Cycles and Policy Subsystems (Vol. 3): Oxford University Press, Oxford. https://doi.org/10.1017/S0008423900007423.

Hughes, O. E. (2012). Public Management and Administration: An Introduction. Macmillan International Higher Education.

Juma, T. O., \& Onkware, K. (2015). The Challenges of Public Policy Formulation and Evaluation through the Questions "What, Who, How, And When. International Journal of Economics, Commerce and Management, 3(11), 830-841. Knill, C., \& Tosun, J. (2008). Policy Making. Comparative Politics, 2(1), 373-388. Lawshe, C. H. (1975). A Quantitative Approach to Content Validity. Personnel Psychology, 28(4), 563-575.

Leroy, P., \& Crabb, A. (2012). The Handbook of Environmental Policy Evaluation: Earthscan.

Link, A. N. (2006). Public/ Private Partnerships: Innovation Strategies and Policy Alternatives. Springer Science \& Business Media.

Liu, J., Love, P. E., Carey, B., Smith, J., \& Regan, M. (2015). Ex-Ante Evaluation of Public-Private Partnerships: Macroeconomic Analysis. 
Journal of Infrastructure Systems, 21(2), 04014038. https://doi.org/10.1061/ (ASCE)IS.1943-555X.0000228.

Matt, E., Givoni, M., Epstein, B., \& Feitelson, E. (2013). Methodology Development for the Evaluation of Policy Instruments to Promote Servicizing. FP7 Project: SPREE (Servicizing Policy for Resource Efficient Economy), Deliverable, 3.

OECD (2013). Public-Private Partnerships in the Middle East and North Africa: A Handbook for Policy Makers: Author Paris, France.

Ostrom, E. (2009). The Institutional Analysis and Development Framework and the Commons. Cornell Law Review, 95(1), 807-816.

Park, H., Lee, S., \& Kim, J. (2018). Do Public Private Partnership Projects Deliver Value for Money? An Ex Post Value for Money (VfM) Test on Three Road Projects in Korea. International Journal of Urban Sciences, 22(4), 579-591. https://doi.org/10.1080/12265934.2018.1455528.

Robinson, H., Carrillo, P., Anumba, C. J., \& Patel, M. (2009). Governance and Knowledge Management for Public-Private Partnerships. John Wiley \& Sons.

Sabatier, P. A. (1991). Toward Better Theories of the Policy Process. PS. Political Science and Politics, 24(2), 147-156.

Sabatier, P. A., \& Weible, C. M. (2014). Theories of the Policy Process. Westview Press.

Saunders, M., Lewis, P., \& Thornhill, A. (2009). Research Methods for Business Students. Pearson Education.

Scriven, M. (1991). Evaluation Thesaurus: Sage.

Treasury, H. M. s. (2007). The Magenta Book: Guidance Notes for Policy Evaluation and Analysis. London: HM Treasury (Magenta Book Background Papers).

Vedung, E. (2009). Public Policy and Evaluation. Transaction Publishers (First Edition in 1997), New Brunswick.

Wollmann, H. (2003). Evaluation in Public-Sector Reform: Concepts and Practice in International Perspective: Edward Elgar Publishing.

Yong, H. K. (2010). Public-Private Partnerships Policy and Practice: A Reference Guide. Commonwealth Secretariat. 